\title{
Research on Present Situation and Measures of University Teachers' Educational Technology Ability Training
}

\author{
$\mathrm{Li} \mathrm{Yu}{ }^{1, a^{*}}$ and Xiaoyue Zhou ${ }^{2, b}$ \\ ${ }^{1}$ Changchun Automobile Industry Institute, Changchun P. R. China \\ ${ }^{2}$ School of Management Jilin University, Changchun P. R. China \\ aperfectamy21st@126.com, ${ }^{\mathrm{b}}$ markruby@sina.com
}

Keywords: University teachers; Educational technology; Ability; Training.

\begin{abstract}
Educational technology can become the driving force of educational reform. Teachers' educational technology ability is the key that educational technology can become the driving force of educational reform. Taking the universities in Changchun as a sample, from four aspects of training system, training content, training methods, training effect, the present situation of university teachers' educational technology ability training is investigated, in order to identify the main problems, and puts forward the countermeasures to strengthen the university teachers' educational technology ability training.
\end{abstract}

\section{Introduction}

The emergence and rapid development of educational technology has brought great changes to education, but the teachers' educational technology ability is the key to realize educational technology as an important power of education reform. Since Higher Education Department of Education Ministry issued "Notice on carrying out the work of College Teachers' educational technology training" in 2000, especially since Ministry of education and Ministry of Finance issued "Opinions on the implementation of the undergraduate teaching quality and teaching reform project of the university "in 2007, all colleges have launched a of different levels, different content and different forms of educational technology training, make the educational technology ability of teachers have been generally improved, effectively promoted the process of teaching informatization of colleges, improve the teaching efficiency, promote the reform of teaching[1]. With the influence of information technology on the development of education, to speed up the process of educational information and to improve the level of teachers' application of information technology is also one of the development tasks of " National Medium-and Long-Term Plan for Education Reform and Development"(2010-2020). In view of this, we conducted a survey on the current situation of the university teachers' educational technology ability training in Changchun in July 2015, in order to bring new ideas for the training.

\section{Design of Current Situation Investigation}

This research is based on the preliminary investigation of the training situation of the university teachers' educational technology ability in Changchun, and from four aspects: training system, training mode, training content, training effect, Research questions were designed, and the questionnaire of the university teachers' educational technology ability training in Changchun was compiled. Take the overall sampling survey in 26 universities in Changchun randomly selected 1 educational technology management personnel as questionnaire object. The sample of colleges and universities including the "985" and "211" universities, 13 ordinary full-time undergraduate colleges and 4 ordinary full-time occupation colleges and technical colleges, 2 adult colleges, 5 Private Colleges. We issued 26 questionnaires, 26 valid questionnaires have been recovered. The survey data were analyzed by SPSS. The sample is shown in Table 1, 
Table 1 Sample schools and information teaching environment

\begin{tabular}{|c|c|c|}
\hline Survey content & Types & Percentage $(\%)$ \\
\hline \multicolumn{3}{|l|}{ School situation } \\
\hline \multirow{4}{*}{ School type } & Comprehensive Universities & 42.3 \\
\hline & Universities of Science and Technology & 19.2 \\
\hline & $\begin{array}{l}\text { Finance and economics politics and Law } \\
\text { University }\end{array}$ & 11.5 \\
\hline & Normal Colleges & 26.9 \\
\hline \multirow{3}{*}{ Number of students } & More than 25000 & 26.9 \\
\hline & $10000-25000$ & 42.2 \\
\hline & Below 10000 & 30.8 \\
\hline \multirow{4}{*}{ Educational Technology Department } & $\begin{array}{c}\text { Independent setting Middle-ranking } \\
\text { institution }\end{array}$ & 34.6 \\
\hline & $\begin{array}{c}\text { Independent setting deputy Middle-ranking } \\
\text { institution }\end{array}$ & 7.7 \\
\hline & $\begin{array}{l}\text { The subordinate institutions of Information } \\
\text { center }\end{array}$ & 11.5 \\
\hline & The subordinate institutions of Idean's office & 46.2 \\
\hline \multicolumn{3}{|l|}{ Information teaching environment } \\
\hline \multirow{3}{*}{ Proportion of multimedia classrooms } & $100 \%$ & 7.7 \\
\hline & $80 \%-99 \%$ & 61.5 \\
\hline & Below $80 \%$ & 30.8 \\
\hline \multirow{3}{*}{$\begin{array}{l}\text { Whether to carry out the network teaching } \\
\text { Whether there is an independent network teaching } \\
\text { platform }\end{array}$} & YES,have an independent platform & 65.4 \\
\hline & YES, Building an independent platform & 26.9 \\
\hline & NO, no independent platform & 7.7 \\
\hline
\end{tabular}

\section{Analysis on the Current Situation of University Teachers' Educational Technology Ability Training}

Training System. 46.2\% of colleges and universities have developed a teacher education technology training management system, and the training work brings into the school or department of the work plan, the corresponding training program was developed. $23.1 \%$ of colleges and universities made mandatory for the training. It can be seen that more than half of the colleges and universities on the teacher education technology training work is not enough attention, has not yet established the necessary rules and regulations, and no perfect related measures to protect the training work. When asked whether it is necessary to strengthen the construction of training system, $96.2 \%$ of people think that it is necessary to develop a teacher education technology training management system, $92.3 \%$ of people think it is necessary to develop teacher education technology training standards.

Training Model. $46.2 \%$ of the universities mainly adopts face-to-face, $30.8 \%$ of the universities take face-to-face and web-based autonomous learning mode, $23.1 \%$ of universities mainly take the way of network autonomous learning; $84.6 \%$ of universities carry out the training for each academic year, among them, $76.9 \%$ of the universities training 1-2 times per academic year, $7.6 \%$ of the university training for 3 times per academic year and above. Overall, the vast most universities each year are carried out educational technology training for teachers. The form of training to focus on short-term training, mainly adopt the face-to-face training mode with Web-based Autonomous Learning

Training Content. The contents and the conditions of the training are shown in Table 2, which shows the training content mainly concentrates in the multimedia teaching, of which $69.2 \%$ carry out the training of the use of multimedia teaching environment, $57.7 \%$ the training of multimedia courseware making, $50 \%$ to carry out the training of multimedia teaching method. $46.1 \%$ to carry out the training of network assisted teaching platform. But most colleges and universities do not pay enough attention to the training of informatization teaching philosophy, theory of educational technology and teaching activities design etc. 
Table 2 The result of teacher education technology training content (\%)

\begin{tabular}{|c|c|c|c|c|}
\hline training content & $\begin{array}{l}\text { At least once a } \\
\text { semester }\end{array}$ & $\begin{array}{l}\text { At least once a } \\
\text { year }\end{array}$ & $\begin{array}{l}\text { Occasional } \\
\text { lecture }\end{array}$ & $\begin{array}{l}\text { Not carried } \\
\text { out }\end{array}$ \\
\hline Introduction to educational technology & 0 & 0 & 11.5 & 88.5 \\
\hline Teaching activity design & 15.4 & 11.5 & 11.5 & 61.5 \\
\hline Multimedia courseware making & 0 & 38.5 & 19.2 & 42.3 \\
\hline Basis of graphics and image processing & 3.8 & 15.4 & 23.1 & 57.7 \\
\hline Basis of audio material processing & 3.8 & 15.4 & 23.1 & 57.7 \\
\hline Basis of video material processing & 0 & 19.2 & 23.1 & 57.7 \\
\hline The use of office automation software & 7.7 & 15.4 & 23.1 & 53.8 \\
\hline Basis of computer network application & 3.8 & 19.2 & 23.1 & 53.8 \\
\hline Multimedia teaching method & 3.8 & 29.9 & 19.2 & 50 \\
\hline Network teaching mode and case & 0 & 26.9 & 19.2 & 53.8 \\
\hline $\begin{array}{l}\text { The use of multimedia teaching } \\
\text { environment }\end{array}$ & 3.8 & 34.6 & 30.8 & 30.8 \\
\hline $\begin{array}{l}\text { The use of network assisted teaching } \\
\text { platform }\end{array}$ & 3.8 & 23.1 & 23.1 & 50 \\
\hline
\end{tabular}

Training Effect. We use likert 5-level to evaluate of training effects and current teacher education technology application level. In the training effect, the score of the three evaluation items were higher. For example, the score of "improved the level of informatization teaching is 3.62; the score of "promoted the improvement of school teaching quality" is 3.46; the score of "Changed the teaching concept of Teachers" is 3.58. It shows that the training has received some results. The evaluation of current teacher education technology application level is shown in Table 3, On the whole, in seven application levels, the mean value of the 4 application level is less than 3 , which is between2-3. The mean value of the 3 application levels is slightly greater than 3 , Indicating that teacher education technology application level in Changchun is not optimistic. The levels of teaching and education theor, multimedia courseware making, network assisted teaching, teaching activity design are in general or below.

Table 3 Current teacher education technology application level score sheet

\begin{tabular}{|c|c|c|c|c|c|c|}
\hline Application project & 1 & 2 & 3 & 4 & 5 & Average score \\
\hline Educational teaching theory level & 3.7 & 30.8 & 46.2 & 11.5 & 3.8 & 2.73 \\
\hline Computer application level & 3.8 & 11.5 & 50.0 & 26.9 & 7.7 & 3.23 \\
\hline Internet application level & 3.8 & 11.5 & 53.8 & 26.9 & 3.8 & 3.15 \\
\hline Proficiency in multimedia teaching equipment & 0 & 15.4 & 57.7 & 26.9 & 0 & 3.12 \\
\hline Multimedia courseware production level & 0 & 42.3 & 46.2 & 11.5 & 0 & 2.69 \\
\hline Network assistant teaching level & 7.7 & 50.0 & 19.2 & 23.1 & 0 & 2.58 \\
\hline Teaching activity design level & 7.7 & 34.6 & 30.8 & 23.1 & 3.8 & 2.81 \\
\hline
\end{tabular}

\section{The Analysis of Main Problems}

Training Policies and Measures. At present domestic university teachers' educational technology ability training mainly by National Council for technical cooperation in Higher Education organizing educational technology department of universities to complete[2]. Because the training ability of each university education technology department is uneven, some provincial (municipalities or autonomous regions ) education administrative departments have actively introduced the relevant training policy, organized and coordinated the relevant training work.

Training Objectives and Content Settings. For college teachers, it does not require everyone to become an expert in educational technology or multimedia development. However, many universities are lack of understanding of the connotation of teachers' educational technology ability, take improving teachers' multimedia courseware making and developing ability as train objectives, make the education technology training change into information technology training[3]. In the training content setting, only pay attention to the technical training, ignoring the learning of concept 
and theoretical, the cultivation of teachers' information literacy and guidance on the application of educational technology

Single Training Forms and Models and Lack of Training Effect Evaluation. Most universities in the form of training to focus on short-term training, mainly adopts the face-to-face mode. The training form and mode is single, is difficult to solve the contradiction in engineering, and can not meet the personalized needs of teachers[4]. In the training effect evaluation, the lack of effective assessment method and quality certification management method, is not conducive to stimulate the enthusiasm of teachers to participate in training. In the training effect, the majority of universities can not transform the training results to teaching practice after training[5]. Due to the lack of technical support, teaching supervision and teaching evaluation of the training teachers in teaching practice use educational technology greatly affects the performance of the training of teachers' educational technology application ability.

\section{Strategy of Strengthening the University Teachers' Educational Technology Ability Training}

Establish the Perfect Training Management System. First of all, it is suggested that the provincial (municipalities and autonomous regions) education departments to draw lessons from the experience of Beijing Municipal Education Commission ,combined with relevant documents on university teachers' educational technology ability training issued by the personnel management department, make the training into teacher training system in universities[6]. Overall planning and design, so that the organization and implementation of training to become an orderly sustainable behavior. Unified planning and layout of the province's training work, Organizing experts and teachers engaged in educational technology research with experience in training to write training programs, training materials, and develop assessment methods. In some universities, to set up training centers by region[7], and to carry out the training in the school and a certain area. At the same time, in order to make the training can continue to effectively carry out, should formulate relevant policies, The assessment results of teachers' training are related to the teacher posts and professional title evaluation, and the training become a necessary condition for the teacher posts and professional title evaluation[8].

Set up Training Objectives and Contents Accurately. University Teachers' educational technology ability includes three aspects: the modern educational idea, information literacy and educational technology application research ability. Therefore, the overall goal of teachers' educational technology ability training should be is to help teachers establish the concept of modern education, to master the basic theory and method of educational technology, improve the application ability of educational technology, to enhance information literacy and professional ability[9]. At the same time, under the premise of follow the overall training objectives, should also help the trainee teachers according to their own inner needs at different levels and stages established in accordance with their actual training target, embodies the people-oriented and individual development

Form and Mode of Reform Training. In the form of training, in accordance with the way that "the combination of long-term and short-term", "the combination of classroom training and extracurricular guidance", "the combination of Classroom centered counseling and network autonomous learning", carry out the training of teachers' educational technology ability in different levels, types and stages. In the training mode, aiming at the characteristics of teachers in training time is tight and heavy teaching tasks, learning ability, adopt a flexible and diversified training model to change currently dominated by face-to-face training mode[10]. Such as "self training + network online training + time focused counseling" mixed mode of training, which make the whole training to teachers self-study, and supplemented by appropriate organizations to guide.

Improve Training Evaluation Method. Change the traditional way of evaluation of closed-book examination and computer practice examination, use flexible evaluation methods to assess the effect of training, pay attention to process evaluation and performance evaluation. For example the trainee teacher's learning performance, task completion, electronic music (teaching 
segment, teaching case)and so on, through self works show, take combination of self-evaluation, group evaluation, classroom teacher evaluation, expert evaluation method, combined with online reviews, field comment, team members online peer assessment, objective evaluation of teacher training performance, strengthen the learning effectiveness of the educational technology training for teachers .

\section{Acknowledgements}

The authors would like to thank Advisory Committee of Foreign Language Teaching in Vocational Education, Ministry of Education of P. R. China under the grant of GZGZ5414-82.

\section{References}

[1] Ding Y., Sang X. The role of educational technology in American colleges and Universities. China university teaching, 2 (2007) 73-76.

[2] Zhou B. The research on Beijing Municipal University of education technology training model [J]. Modern Educational Technology, 20(2010)62-64.

[3] Ding W., Yan W. Analysis on the current situation of College Teachers' educational technology ability. E-education Research, 9(2010)64-69.

[4] ZhenS., Jian L. Management problems of the training of teachers - with modern educational technology training management as an example. Research in Education Development, 8(2008)79-82.

[5] Hong Z. Cultivation of College Teachers' educational technology ability under the information environment. Modern Educational Technology, 20 (2010)139-143.

[6] Wang L.New probes of the current training of high school teachers. Science and Education Research, 36(2014) 223-225.

[7] Yan Y. Building the system of supporting teachers` training. Vocational Research, Z1 (2009) 76-82.

[8] Liao N.Traning capabilities of university teachers. Vocational Research, 1 (2008) 54-56.

[9] Wang D., Wang L. Research on the success of a university teacher. Vocational Research, 1(2010)154-155.

[10]Ren P. The SWOT analysis of teachers` teaching abilities. Vocational Tech Education, 3(2012)100-103. 